\title{
Nietzsche e o transhumanismo como sintoma do ideal ascético
}

Nietzsche and transhumanism as a symptom of the ascetic ideal

LUCIANA ZATERKA

\section{Resumo}

Ao lado das imagens já conhecidas de Nietzsche como "precursor do nazismo", "racista", "pós-moderno", "pensador perigoso e irracionalista", em tempos recentes acrescentou-se à imagem de "precursor do transhumanismo". Ao apresentarmos aqui alguns elementos do transhumanismo, em especial aqueles ligados às mais recentes biotecnologias, bem como alguns conceitos do pensamento de Nietzsche, em especial o além-do-homem e a ontologia da imanência do vir-a-ser, visamos ampliar esse debate, enfatizando que, para Nietzsche, o ideal transhumanista não seria mais do que um sintoma do ideal ascético, tão presente ainda na nossa contemporaneidade.

Palavras-chave: Nietzsche. Transhumanismo. Ideal ascético. Sofrimento.

\section{Abstract}

In addition to the already known images of Nietzsche as "precursor of nazism", "racist", "postmodern", "dangerous and irrationalist thinker", in recent times the image of Nietzsche's "precursor of transhumanism" has been added. By presenting here some elements of transhumanism, especially those related to the most recent biotechnologies, as well as some concepts of Nietzsche's thought, especially the overhuman and the ontology of the immanence of becoming, we aim to expand this debate, emphasizing that for Nietzsche the transhumanist ideal would be nothing more than a symptom of the ascetic ideal, which is still present in our contemporaneity.

a Universidade Federal do ABC (UFABC), São Paulo, SP, Brasil. Doutora em Filosofia, e-mail: zaterka@uol.com.br 
Keywords: Nietzsche. Transhumanism. Ascetic ideal. Suffering.

\section{Introdução}

Ao lado das imagens já conhecidas de Nietzsche como "precursor do nazismo", "racista", "pós-moderno", "pensador perigoso e irracionalista", em tempos recentes acrescentou-se a imagem de Nietzsche como "precursor do transhumanismo". De fato, em alguns artigos publicados a partir de 2009 no Journal of Evolution and Technology ${ }^{1}$, Stefan Sorgner, filósofo alemão e professor da John Cabot University, enfatiza o que considera importantes semelhanças entre o atual movimento transhumanista e o pensamento nietzschiano. Sorgner acredita que essa aproximação se daria em torno principalmente de dois conceitos. Em primeiro lugar, os transhumanistas afirmam o vir-a-ser da natureza, a sua transitoriedade e, portanto, acreditam numa ontologia dinâmica subjacente ao mundo: "o mesmo ocorre com Nietzsche, já que ele acredita em uma dinâmica da metafísica da vontade de poder que se aplica a todos os seres,

${ }_{1}^{1}$ Por exemplo, cf. Journal of Evolution and Technology, v. 20, n. 1, 2009; v. 21, n. 2 (2010).

Rev. Filos., Aurora, Curitiba, v. 32, n. 55, p. 74-91, jan./abr. 2020 
incluindo os seres humanos, o que implica que todas as coisas estão constantemente experimentando a mudança" (SORGNER, 2009, p. 30). Como desdobramento imediato desse posicionamento ontológico, encontraríamos, da parte dos transhumanistas, a crença de que "a espécie ser humano não é fixa e nem imutável [...], pode então evoluir para uma espécie diferente” (SORGNER, 2009, p. 30). Neste sentido, esse movimento de pensamento acredita e enaltece as alterações e manipulações do humano, por meio das ciências e das mais recentes tecnologias, com vista ao melhoramento da nossa espécie. Nietzsche, por seu turno, teria afirmado que tudo no mundo ocorre por um efetivar-se de forças (Kräfte). O homem como todos os outros seres são inacabados, transitórios, alteráveis, "pontes e não metas", fluxos em eterna mutação. Desta maneira, o filósofo da suspeita teria também criticado enfaticamente a noção de natureza humana, estável e permanente, e assim considerava que as mudanças ou as modificações são partes constitutivas do vir-a-ser e do processo das forças que compõem o mundo. Essa visão dinâmica nos levaria para o segundo ponto levantado por Sorgner. Ao afirmar a "morte de Deus", o autor do Zaratustra teria destruído toda a metafísica ocidental, todo o âmbito da transcendência e afirmado que, de agora em diante, o homem deve permanecer "fiel à terra, a essa terra". Isso significa que, ao introduzir o seu difícil conceito de além-do-homem (Übermensch), Nietzsche apostava numa concepção futura de humanidade que tenha como base a imanência, e não mais a transcendência. Assim, nosso pensador, tendo antecipado algumas inquietudes e desafios de nosso século, teria proposto, por meio do método genealógico, um diagnóstico do homem moderno. Ao se perguntar pelo valor dos valores, o pensador alemão começava por suspeitar da religião e da moral. Nesta empreitada, o cristianismo, sem dúvida, foi considerado como o principal alvo de Nietzsche, afinal a tradição cristã colocara sob a marca do pecado todo o âmbito do corpóreo, da fidelidade à terra, os desejos, as paixões, o corpo; enfim, em face de uma promessa eterna e paradisíaca no além, tal tradição deixa de lado tudo aquilo que de fato importa à vida, isto é, a própria vida terrena. Ora, segundo Sorgner, os 
transhumanistas também são críticos da tradição judaico-cristã ${ }^{2}$, pois os valores dessa longeva tradição não conseguem mais dar conta dos avanços da nova ciência e das recentes tecnologias. Assim, a imortalidade não deve mais ser buscada no além, mas na própria vida presente; no limite, os transhumanistas buscam a "morte da morte", por meio de uma nova concepção de imanência.

Porém, se Sorgner ficou bastante conhecido sobretudo com o seu artigo Nietzsche, the Overhuman, and Transhumanism ${ }^{3}$, é bom lembramos que doze anos antes, Keith Ansell Pearson, no seu Viroid Life (1997), já havia problematizado a questão, aliás mostrando que a possível relação entre o movimento contemporâneo e a filosofia de Nietzsche é no mínimo problemática, pois diferentemente do transhumanismo, o pensamento nietzschiano não opera com dicotomias, tais como humano/pós-humano, passado e futuro, etc., muito menos com a separação entre orgânico e tecnológico (PEARSON, 1997). A corrente filosófica que prega a superação da mortalidade humana por meio das mais recentes tecnologias seria ainda, segundo o Nietzsche de Ansell Pearson, defensora de uma visão antropomórfica e ligada ao ascetismo. Voltaremos a esse último ponto mais adiante. Em 2017, vários estudiosos de Nietzsche publicaram um importante livro Nietasche and the Transhumanism: Precursor or Enemy, editado por Yunus Tuncel, no qual se retoma e amplia as discussões iniciadas por Sorgner. Um dos artigos nele contido, por exemplo, mostra com riqueza e seriedade a amplitude conceitual do movimento do transhumanismo que, então, pôde acolher inúmeras e diversas interpretações filosóficas, desde Nietzsche, passando pelo anarquismo, comunismo, eugenismo, liberalismo, etc. (BLACKFORD, 2017). Não podemos ainda esquecer dos vários artigos que apareceram em The Agonist ${ }^{4}$, todos

\footnotetext{
${ }^{2}$ Lembro aqui as palavras de Max More no seu Transhumanism: Toward a futurist philosophy: "[...] A humanidade está nos estágios iniciais de um período de expansão explosiva no conhecimento, liberdade, inteligência, expansão de vida, e sabedoria. Contudo, nossa espécie persiste em velhas estruturas e processos conceituais que atuam como entrave ao progresso. Um dos piores é o pensamento religioso. Neste ensaio, mostrarei como a religião age como uma força entrópica, paralisando o nosso avanço para o transhumanismo e nosso futuro como pós-humanos [...]. A alternativa à religião não é um niilismo desesperador, nem um cientismo estéril, mas o transhumanismo"; cf. More, 1990, p. 6.

${ }^{3} \mathrm{O}$ primeiro dos dois artigos, cujas referências constam da nota 1 acima.

${ }^{4}$ Cf. <http://agonist.nietzschecircle.com/wp/staff/>.
} 
escritos por nietzschianos, como o já referido Keith Ansell Pearson e Babette Babich, que de maneira geral apontam para o distanciamento entre as duas filosofias, demonstrando que tanto a matriz conceitual de ambos quanto a finalidade de seus empreendimentos filosóficos são absolutamente distintos. Não pretendemos aqui fazer uma genealogia exaustiva deste debate, mesmo porque seria impossível abordá-lo na sua complexidade e totalidade; apenas pretendemos enfatizar que existe um debate sério e fértil sobre a temática exposta; e que focar em alguns elementos desta discussão talvez nos ajude a avançar, no sentido de refletir sobre um dos principais objetivos do ideal transhumanista, qual seja, a superação da finitude humana e, com isso, a supressão das nossas dores e sofrimentos por meio das mais recentes tecnologias.

\title{
O transhumanismo e a superação da finitude humana
}

A palavra transhumanismo foi utilizada pela primeira vez pelo biólogo britânico Julian Huxley (1887-1975), na sua obra de 1927, intitulada Religion without Revelation:

\begin{abstract}
A espécie humana pode, se assim o desejar, transcender-se a si mesma - não apenas esporadicamente um indivíduo aqui de uma certa maneira, um indivíduo ali de outra, mas como humanidade. Precisamos de um nome para essa nova crença. Transhumanismo serve porque 0 homem continua a ser homem, mas transcendendo-se graças às novas possibilidades de e para a sua natureza humana (HUXLEY, apud BOSTROM, 2005a, p. 7).
\end{abstract}

A temática propriamente dita somente ganha densidade epistêmica quando nomes importantes ligados ao transhumanismo, como Max More e Nick Bostrom, enfatizam alguns dos fundamentos conceituais norteadores do movimento": "é uma filosofia que busca nos guiar em direção a uma condição pós-humana"”, condição essa

\footnotetext{
${ }^{5}$ Entre os principais representantes do movimento encontramos Max More (Grã-Bretanha), Nick Bostrom (Suécia), Julian Savulesco (Austrália), David Pearce (Grã-Bretanha), Richard Dawkins (Estados Unidos), Laurent Alexandre (França). Tal movimento recebe apoio de várias associações internacionais, por exemplo, o Extropy Institute (http://www.extropy.org/) e a World Transhumanist Association (https://humanityplus.org/).

${ }^{6}$ Max More (1990) escreve em seu Transhumanism: toward a Futurist Philosophy: "[...] a filosofia que busca nos guiar em direção a uma condição póshumana. Trans-humanismo compartilha muitos elementos do Humanismo, incluindo o respeito pela razão e pela ciência, um compromisso com o progresso e uma valorização da existência humana (ou transumana) 'terrena', em vez de alguma pós-vida sobrenatural. Trans-humanismo difere do humanismo ao reconhecer e antecipar as radicais alterações na natureza e as possibilidades de nossas vidas resultantes de várias ciências e
} 
que nos daria maior liberdade, conhecimento e sobretudo longevidade ${ }^{7}$ Em outras palavras, há uma crença que por meio das técnicas mais recentes, tais como a engenharia genética, a biologia molecular, a robótica, as neurociências cognitivas, a biotecnologia, a neurofarmacologia, a nanotecnologia, etc., conseguiremos nos livrar do âmbito da contingência, ou seja, da condição a que temos nos submetido desde o advento da descrição do processo evolutivo por Darwin, n’A Origem das espécies (1859), que nos fez da maneira que somos, primatas falantes e inteligentes, mas submetidos a múltiplas limitações que podem ser superadas tecnologicamente. Portanto, teria chegado a hora do ser humano tomar as rédeas e o controle de sua própria evolução e torná-la uma evolução dirigida e planejada, em direção a uma evolução não mais simplesmente biológica, mas sobretudo tecnológica (DIÉGUEZ, 2016, p. 41). Bostrom, por exemplo, sintetiza bem essa perspectiva no seu Transhumanist Values:

Nada de errado sobre "modificar a natureza"; a ideia de hýbris foi rejeitada. A escolha individual na utilização de tecnologias de aprimoramento, liberdade morfológica (...). Ficar mais inteligente (individualmente, coletivamente, e desenvolver a inteligência de máquina); Falibilismo Filosófico, disposição de reexaminar os pressupostos à medida em que avançamos; Pragmatismo, espírito engenheiro e empreendedor, ciência [...]. Salvando vidas (prolongamento da vida, antienvelhecimento, pesquisa e preservação criogênica) (BOSTROM, 2005b, p. 13).

Tais objetivos poderiam ser alcançados por meio de duas vias distintas: pelo âmbito da engenharia e da inteligência artificial, ou seja, pela transferência do conteúdo da mente humana para um disco rígido de um hipercomputador, processo conhecido como mind uploading, no qual todos os dados do cérebro humano seriam transferidos

tecnologias, tais como a neurociência e a neurofarmacologia, o prolongamento da vida, a nanotecnologia, a ultra-inteligência artificial, combinadas com uma filosofia racional e um sistema de valores" (p. 6-7).

7 Nome importante também deste movimento, considerado um de seus iniciadores, é F. M. Esfandiary (1930-2000). Em seu livro Are you a Transhuman? Monitoring and Stimulating Your Personal Rate of Growth In a Rapidly Changing World, o filósofo, nascido em Bruxelas, discute a intrínseca relação entre os novos recursos tecnológicos e às mudanças dos hábitos de vida. 0 trans-humano, esse ser em transformação, além de progredir no âmbito tecnológico, aperfeiçoa-se nas esferas culturais e éticas, e assim por volta do final do século XXI poderá ascender a uma nova categoria, a de pós-humano. Em Esfandiary o conceito de pós-humano aparece atrelado à colonização espacial. Segundo ele, a exploração do espaço sideral "acelera nossa transformação de organismos humanos/animais específicos da Terra para extraterrestres póshumanos" (ESFANDIARY, 1989, p. 110). O acesso a novas dimensões espaciais levaria a novas conexões com outras espécies inteligentes e, consequentemente, a um "poderoso impulso para a frente". 
para o "cérebro" de um computador ${ }^{8}$; ou pelo âmbito da manipulação genética de nossa espécie, perspectiva essa que nos interessa mais de perto, pois carrega em seu processo a possibilidade de extinguir as dores e sofrimentos que sempre foram inerentes à condição humana. Essa perspectiva pode ser observada na importante Declaração Trans-Humanista (1983), publicado na Internet por Natasha Vita More, Presidente do Conselho de Diretores da Humanidade $+{ }^{9}$. No artigo oito do documento, por exemplo, lemos:

Defendemos que os indivíduos tenham uma ampla escolha pessoal sobre como conduzir suas vidas. Isso inclui o uso de técnicas que podem ser desenvolvidas para ajudar a memória, concentração e energia mental; terapias para prolongamento da vida; tecnologias para escolha reprodutiva; procedimentos criogênicos e muitas outras tecnologias possíveis para a modificação e melhoria (aprimoramento) do ser humano.

A superação da finitude por meio da manipulação genética de nossa espécie está, sem dúvida, na pauta do dia. De fato, especialistas, como o biólogo e filósofo Andrés Moya, de Valência, Espanha, mostram que a ampla incorporação de enfoques e metodologias provenientes da engenharia converteram a biologia sintética em uma tecnociência com uma capacidade de transformação única, muito maior do que a da engenharia genética clássica. Surgida a partir das técnicas de transgenia, que permitem, sabemos, alterar um organismo inserindo ou removendo pedaços de DNA de seu genoma, a biologia sintética tem a capacidade de criar organismos feitos "sob medida". Da mesma maneira que um engenheiro elétrico consegue construir e controlar um circuito elétrico, o engenheiro genético objetiva domesticar o mecanismo de replicação e transcrição do DNA, de modo a controlar o seu funcionamento (EL-HANI, 2008). Como as dificuldades para se desvendar as partes componentes do sistema e suas interações não são poucas, desde o final da década de noventa do século passado foram propostos alguns padrões; o mais aceito e utilizado até hoje pela comunidade científica são os biobricks (biotijolos, por analogia com o brinquedo de montar peças “Lego"), desenvolvidos a partir de 2003 por pesquisadores do Massachussets Institute of Technology (MIT), como o cientista Tom Knight. Desde então, existe uma preocupação com o

\footnotetext{
8 Para maiores informações sobre esta técnica, cf. Sandberg, A.; Bostrom, N. (2008). ${ }^{9}$ Para consultar a Dedaração Trans-humanista, of. https://humanityplus.org/philosophy/transhumanist-dedaration/.
} 
desenvolvimento e definição destas partes biológicas padrão, para garantir que as peças biológicas produzidas possam ser montadas e trocadas com facilidade pelos componentes biológicos sintéticos ao redor do mundo (SHETTY, 2008). Cada biobrick é uma sequência de DNA transportada em um plasmídeo. Ele consiste em um vetor circular de dupla fita de DNA contendo a sequência que codifica uma função biológica definível e um componente biológico padrão para ser uma parte biológica que foi refinada para estar em conformidade com um ou mais padrões técnicos predefinidos. As sequências de nucleotídeos dos biobricks são projetadas para serem montadas na construção de novos circuitos e sistemas biológicos com aplicações específicas; por exemplo: síntese de proteínas e produção de compostos. As sequências dos biobricks estão disponíveis no Registry of Standart Biological Parts (RSBP) do MIT ${ }^{10}$. Essa metodologia abre as portas para a possibilidade de fabricação da síntese de novas drogas apropriadas para agir como potenciadores de nossas faculdades, físicas e mentais, com capacidade para aumentar significativamente a duração de nossa vida, fornecendo adicionalmente uma qualidade inimaginável até agora. Esperam também, acima de tudo, que as técnicas e conhecimentos sirvam para criar em laboratório novos genes, desconhecidos na natureza, que, uma vez inseridos no genoma humano, teriam efeitos ainda mais radicais. Estes genes poderiam conter novos códons que modificariam o código geneticamente, a ponto, por exemplo, de serem capazes de bloquear a replicação dos vírus por meio do mecanismo celular de tradução, tornando as nossas células imunes aos ataques. A modificação de nosso genoma iria, então, aumentar gradualmente até finalmente gerar uma nova espécie biológica. Uma nova espécie que iria nos separar ainda mais de qualquer primata. Essa nova espécie seria, portanto, sobre-humana ou transhumana.

Já o pesquisador Dr. Michael D. West, fundador da empresa Agex Therapeutics ${ }^{11}$, que trabalha na área de rejuvenescimento e prolongamento da vida, objetiva descobrir

\footnotetext{
${ }^{10} \mathrm{Cf} .<$ https://igem.org/Registry>.

11 Lemos na página inicial do site: "A AgeX Therapeutics está focada no desenvolvimento e comercialização de novas terapêuticas direcionadas ao envelhecimento humano. Estamos construindo sobre as bases de nossas próprias tecnologias, como a PureStem e induced Tissue Regeneration $\left(i T R^{t m}\right)$ o desenvolvimento de medicamentos inovadores projetados para resolver
} 
os processos que podem conduzir à imortalidade celular, estudando os telômeros, porções do DNA que se localizam na extremidade dos cromossomos. Grosso modo, sua principal função é proteger o material genético de degradação. Ora, a cada replicação, essas partes do DNA diminuem, pois o processo de replicação não consegue copiar as extremidades dos cromossomos. Com a idade, os corpos acabam acumulando telômeros curtos e como consequência essas células encurtadas trazem o envelhecimento e os males da velhice. Assim, nossa “data de validade biológica” está ligada ao comprimento dos telômeros. As pesquisas do Dr. West focam na telomerase, na proteína que tem a capacidade de regenerar os telômeros, alongando-os ${ }^{12}$. A expressão da telomerase ocorre nas células de linhagem germinativa, nas células-tronco e nas células neoplásicas, havendo nessas células uma regeneração dos telômeros e prevenção da senescência replicativa. No entanto, a maioria das células humanas somáticas normais apresenta pouca ou nenhuma atividade de telomerase. Desta perspectiva, Dr. West declara ter começado a trabalhar numa importante pesquisa sobre linhas germinativas, uma "verdadeira fonte de imortalidade". Esse trabalho opera com a distinção clássica entre linha germinativa e soma. As linhas germinativas compreendem espermas e óvulos, e as células da quais elas derivam, espermatócitos e espermatogônias, bem como as células de "fundo" da linha germinativa, gametócitos e gametogonias; pela sua natureza, elas possuem a capacidade de existir para sempre. O soma, por sua vez, é o conjunto de todas as outras células que compõem o corpo humano e, ao contrário das primeiras, ele adoece, envelhece e morre. Os cientistas que trabalham com o Dr. West objetivam aproximar o soma da linha germinativa, como explica Roberto Manzocco:

\footnotetext{
alguns dos maiores problemas não resolvidos acerca do envelhecimento. Através do PureStem, temos a capacidade de gerar células jovens pluripotentes derivadas de células-tronco de qualquer tipo para aplicação potencial em uma variedade de doenças degenerativas do envelhecimento com uma alta necessidade médica não atendida. O $I T R^{T M}$ é nossa plataforma revolucionária de longevidade, com o objetivo de desbloquear a imortalidade celular e a capacidade regenerativa de reverter mudanças no corpo relacionadas à idade"; cf. <https://www.agexinc.com/>.

${ }^{12}$ Em fevereiro de 2018, Yinnan Chen, que trabalha no Departamento de Química e Bioquímica da Universidade do Arizona, publicou um artigo explicando o funcionamento deste completo processo, cf. Chen, Y. et al. A single nucleotide incorporation step limits human telomerase repeat addition activity, Embo J, n. 37, 2018.
} 
De um ponto de vista prático, isso significa trabalhar numa expressão importante da linha germinativa, as células tronco, células que podem se transformar em qualquer tipo de tecido. Se conseguirmos dominar este processo, poderemos curar um enorme número de diferentes patologias degenerativas, da doença de Alzheimer à distrofia muscular. E, como essas células ainda não decidiram se serão células germinativas ou somáticas, elas ainda não são prisioneiras da mortalidade do soma e realmente desfrutam da imortalidade da linha germinativa, o que significa que eles podem proliferar indefinidamente (MANZOCCO, 2019, p. 96-7).

Assim, a porta para as clonagens terapêuticas em humanos está aberta e o sonho da imortalidade cada vez mais perto. Esses exemplos nos mostram que as pesquisas mais recentes em ciência e tecnologia estão, de fato, cada vez mais próximas de auxiliar a realização do sonho transhumanista ${ }^{13}$, de alcançarmos a longevidade e quiçá a imortalidade e, nesse sentido, o desenvolvimento da biotecnologia está investindo fortemente na concepção transhumanista de Human Plus e Human Enhacement, ou seja, humanos mais positivados e aperfeiçoados. Se a aplicação de técnicas de manipulação e artificialização da vida e o horizonte biotecnocientífico continuar nessa progressão, supõe-se que perto dos anos de 2050 conseguiremos, segundo os transhumanistas, dar um plus na humanidade, tornando-a mais feliz, longeva e saudável, e aproximando-a de uma natureza pós-humana ou transhumana. Enfatizando esses aspectos, Nick Bostrom escreveu, num texto intitulado In Defense of Posthuman Dignity, que o grande objetivo deste movimento é aumentar a longevidade humana, erradicar doenças, dores e sofrimentos, bem como atingir "saúde ilimitada, faculdade intelectuais maiores do que quaisquer seres humanos atuais, talvez sensibilidades inteiramente novas, e a capacidade de controlar suas próprias emoções" (BOSTROM, 2005c, p. 202). E aqui chegamos num ponto essencial da nossa discussão. Qual o sentido de atingirmos esses meios capazes de extinguir as nossas dores, emoções e sofrimentos? Tentaremos responder a

13 Lembremos ainda dos experimentos envolvendo a técnica da parabiose, experimento que objetiva compartilhar o fluxo sanguíneo de dois seres que ficam então unidos por meio de suas veias. Irving Weissman (1980) e Thomas A. Rando (1994), ambos da Universidade de Stanford, foram os primeiros a operarem com a parabiose com a finalidade de estudar as células-tronco do sangue. Em 2013, a equipe de Amy Wagers, especialista em medicina regenerativa da Universidade Harvard, publicou um artigo na revista Cell em que, por meio da parabiose, identificou em camundongos velhos que receberam sangue de animais jovens o aumento de uma proteína que combateria disfunções cardíacas ligadas à velhice. De fato, após anos de pesquisas complexas, a equipe de Harvard conseguiu isolar uma proteína "do sangue jovem" (GDF11) que parece reparar a arquitetura do coração, a vasculatura do cérebro e partes dos músculos, cf. Conese, M., et al. (2017). 
essa questão nos voltando para a nossa proposta inicial. Pois, agora, acreditamos poder problematizar o "sentido do transhumanismo" examinando a reivindicação de alguns dos transhumanistas de se filiarem filosoficamente ao pensamento de Nietzsche. É uma reivindicação legítima? Não haveria aí um certo uso ideológico ou metafísico do pensador alemão?

\section{Nietzsche e o locus do sofrimento humano}

No Prólogo do Zaratustra, Nietzsche escreve alguns dos fragmentos mais conhecidos de sua filosofia:

Eu vos ensino o super-homem. O homem é algo que deve ser superado, Eu vos imploro, irmãos, permanecei fiéis à terra e não acrediteis nos que vos falam de esperanças supraterrenas! São envenenadores, saibam eles ou não. São desprezadores da vida, moribundos que a si mesmos envenenaram, e dos quais a terra está cansada: que partam, então!, O homem é uma corda, atada entre o animal e o além-do-homem - uma corda sobre um abismo. Um perigoso para-lá, um perigoso caminho, um perigoso olhar-para-traz, um perigoso estremecer e se deter. [...] uma ponte e não um objetivo [...] uma passagem e um declínio (NIETZSCHE, 2011, p.13-16).

Por meio deles Nietzsche afirma um plano de imanência constituído por forças em ação, em pleno devir, que deveria nos conduzir para uma nova concepção de humanidade, o além-do-homem. Mas qual o sentido preciso desta nova concepção? Tendo vivido durante a segunda metade do século XIX, Nietzsche não faz menção em suas obras a viagens espaciais e civilizações extraterrestres, não aborda também nenhum tipo de aperfeiçoamento tecnológico do corpo humano. Assim, o seu ponto de vista concentra-se principalmente na criação de novos valores. Na Genalogia da Moral, ao se perguntar pelo "valor dos valores", ele critica e demole toda a moral vigente, em especial a tradição platônico-cristã. Para o pensador alemão, essa tradição vive a vida com culpa, vergonha, ressentimento, e assim teme o vir-a-ser e toda a efetividade, acreditando em uma redenção por meio da transcendência. Ora, com doutrina da "morte de Deus", a divinização do além fica interditada, não se deve mais buscar alívio para nossas dores e sofrimentos num mundo transcendente. Daí a importância do projeto nietzschiano de transvaloração dos valores, uma proposta na qual os valores 
devem ser regulados pela imanência, e o grande objetivo é o desvencilhamento dos valores morais de cunho transcendente, religioso, dogmático. Por meio da queda destes valores "decadentes e ascéticos", o além-do-homem poderia finalmente vivenciar a imanência com tudo que ela carrega, inclusive a contingência, as dores e os sofrimentos. $\mathrm{E}$ aqui podemos começar a notar que há um distanciamento entre o projeto nietzschiano e os valores ditados pelo transhumanismo.

Zaratustra afirma que o homem precisa vencer a si mesmo, ou seja, superar os seus limites pessoais, para que atinja a plena capacidade de conquistar a si próprio. Mas Nietzsche é claro: superar, não aniquilar. Isso significa que as fraquezas, dores e sofrimentos que constituem o humano não devem ser destruídos: "Criar - eis a grande libertação do sofrer, e o que torna a vida leve. Mas para que haja o criador é necessário sofrimento, e muita transformação. Sim, é necessário que haja muitos amargos morreres em sua vida, ó criadores!” (NIETZSCHE, 2011, p. 82). Veremos que, ao colocar a tradição cristã de um lado e a tradição dionisíaca de outro, Nietzsche pretende abordar com clareza o problema do sofrimento. Num aforismo redigido em 1888, assevera:

[...] O ser humano trágico afirma inclusive o sofrimento mais áspero: é bastante forte, pleno, deificante para fazê-lo. O cristão nega inclusive o mais feliz dos destinos sobre a Terra: é bastante fraco, pobre, deserdado para sofrer ainda em toda forma de vida. 'O Deus na cruz' é uma maldição contra a vida, uma indicação para libertar-se dela. O Dioniso cortado em pedaços é uma promessa de vida: esta eternamente renascerá e da destruição retornará" (FP, 1888,14 [89]).

A superação proposta por Nietzsche é de outra natureza, distinta da proposta pelo ideal transhumanista, afinal não são as nossas fragilidades, dores e 'incompletudes naturais' que devem ser superadas, e muito menos, a finitude. A fidelidade à imanência tão enfatizada pelo pensador alemão é uma fidelidade a tudo o que é mundano, corporal, sensível, terreno, aí incluídas as nossas aflições, inquietudes, angústias e doenças. No aforismo 49 de Aurora, intitulado "O novo sentimento fundamental: somos definitivamente efêmeros", lemos:

Antigamente buscava-se o sentimento de grandeza do homem apontando para sua origem divina: este se tornou um caminho proibido, pois sobre o umbral está o macaco, junto com outras bestas medonhas: compreensivo, ele arreganha os dentes como a dizer: nenhum passo a mais nessa 
direção! Tenta-se agora, portanto, a direção oposta: o caminho que a humanidade está tomando servirá como prova de sua grandeza e sua filiação divina. Ai, o esforço também é em vão! No fim desse caminho constrói-se a urna funerária do último homem, do coveiro (com a inscrição "nihil humani a me alienum puto" [nada humano me é estranho!]. Por mais que a humanidade tenha evoluído - e talvez ao final ela acabe em um nível ainda mais baixo do que no início! - ela não pode passar para uma ordem superior, tanto quanto a formiga e a lacraia podem, no término de seu "curso terreno" elevar-se à filiação divina e à vida eterna. O vir-a-ser arrasta atrás de si o-que-já-foi: porque fazer uma exceção a este eterno espetáculo em benefício de algum vago planeta e depois de alguma vaga espécie sobre ele! Basta desses sentimentalismos!

É por isso que o transhumanismo seria, como afirmou Ansell Pearson, simplesmente mais um sintoma do ideal ascético, tão criticado por Nietzsche. Como bem mostrou Babett Babich, os transhumanistas desejam, é verdade, a vida, mas não a aceitam e a acolhem como ela é, com todos os seus problemas, banalidades e limitações: "Se nós nos tornarmos máquinas, não conseguiremos como na promessa cristã de reencarnação, recuperar os nossos corpos obsoletos? (BABICH, 2017, p. 123). Assim, do ponto de vista dos transhumanistas, o que deve ser superado é a nossa "incompleta" natureza, aquilo que ironicamente a filosofia nietzschiana afirma: corpos, dores, emoções, inquietudes e sofrimentos. O problema no fundo é que o transhumanismo seria uma forma às avessas do niilismo religioso, que condena a vida aqui e agora, projetando indefinidamente um futuro redentor. Contudo, não é Deus que irá nos redimir, mas as técnicas da biotecnologia, inteligência artificial, nanotecnologia, robótica, criogenia, etc. Assim "o que liga o transhumanismo de forma mais estreita ao ideal ascético é o desejo de superar completamente o sofrimento, além de sua inabilidade em afirmar o sofrimento como uma parte da vida" (WOODWARD, 2016, p. 293). Desta maneira, observamos domínios ontológicos diametralmente opostos entre as duas filosofias, como podemos ler no aforismo 25 da III Dissertação da Genealogia da Moral:

Ambos, a ciência e o ideal ascético, acham-se no mesmo terreno - já o dei a entender -: na mesma superestimação da verdade (mais exatamente: na mesma crença na inestimabilidade, incriticabilidades da verdade), e com isso são necessariamente aliados - de modo que, a serem combatidos, só podemos combatê-los e questioná-los em conjunto. Uma avaliação do ideal ascético conduz inevitavelmente a uma avaliação da ciência: mantenham os olhos e os ouvidos abertos para esse fato (NIETZSCHE, 1988, p. 174).

E não poderia ser diferente, pois os empreendimentos filosóficos em questão operam com noções de temporalidade também distintas. Nietzsche mais próximo, 
como vimos no fragmento acima, do simbolismo dionisíaco, acreditava que a vida mesma implica o retorno. De um lado Dioniso ${ }^{14}$, aquele que aceita a vida como ela é e seu "eterno retorno", inclusive com seus tormentos e sofrimentos: "Zaratustra, o semdeus, te chama! Eu, Zaratustra, o porta-voz da vida, o porta-voz do sofrimento, o porta-voz do círculo, — te chamo a ti, ó meu pensamento mais abissal!” (Zaratustra, III, O convalescente; NIETZSCHE, 2011, p. 207). De outro lado, Cristo, o negador da vida, que não aceita a existência como ela se apresenta. Ao contrário desse movimento filosófico transhumanista, que se apoia no desenvolvimento científico e tecnológico, que acredita na perfectibilidade humana, aquela mesma fundada no iluminismo e no cientificismo, no projeto empírico-experimental moderno e, assim, promete a superação das nossas fraquezas e sofrimentos, Nietzsche por sua vez as reafirma. De um lado, encontramos uma concepção linear de história, presente em toda tradição religiosa e científica ocidental, que afirma a crença no progresso e assim acredita num caminhar contínuo inserido num tempo homogêneo, vazio e cumulativo que se dirige para um fim, um télos. Dos projetos modernos de Descartes e Bacon, passando pelo corpo máquina de La Mettrie, enfatizando a ideia de perfectibilidade de Condorcet e Rousseau, chegando à maioridade moral kantiana, encontramos o mesmo solo filosófico-científico caro aos transhumanistas e tão questionado por Nietzsche. Nietzsche, crítico feroz do positivismo e do iluminismo, não pretende, como vimos, aperfeiçoar, ou melhorar, o homem ${ }^{15}$ : "Melhorar a humanidade?", escreve ele no

\footnotetext{
${ }^{14}$ Nietzsche retoma em vários momentos de sua obra o mito grego de Dioniso. Conhecido por ser o deus da dança, do vinho e da embriaguez, tem um local importante na obra de Nietzsche, pois ele representa a plena aceitação do caráter trágico da existência. A posição dionisíaca não é, pois, crítica ou negativa, mas, ao contrário, de plena afirmação da existência. O trágico é força criativa e instintiva. É por isso que em alguns momentos Nietzsche prefere referir-se ao âmbito artístico do que ao científico. Neste sentido, Dioniso está relacionado com outra concepção temporal a do "eterno retorno", que então conceituará a história como eternamente autocriadora e autodestruidora. Com esse pano conceitual em mente, nosso pensador poderá, então, criticar conceitos como os de aperfeiçoamento, teleologia, perfectibilidade, linearidade e progresso, que na sua perspectiva são valores decadentes incrustados no âmbito da tradição metafísico-religiosa.

${ }^{15}$ Acompanhamos aqui a interpretação de Jelson Roberto de Oliveira: "Certamente poderíamos incluir o trans-humanismo entre as 'tendências mais diversas' do projeto de melhoramento criticado por Nietzsche e, por essa via, também por ele alcançaríamos o adoecimento do homem. Isso porque, como ocorrera nos projetos do passado, também agora a moralidade é colocada a serviço da negação das características humanas, demasiado humanas, principalmente no que elas teriam de aproximação com o animal do homem, ou seja, com a sua animalidade. Nesse sentido, o
} 
Prólogo 2 do Ecce Homo: "Eis a última coisa que eu prometeria. Não esperem de mim que eu erija novos ídolos! Que os antigos aprendam antes quanto custa ter pés de barro! Derrubar 'ídolos' — é assim que chamo todos os ideais —, esse é meu verdadeiro ofício [...]" (NIETZSCHE, 1995, p. 18).

\section{Considerações finais}

Ao apresentar alguns elementos que afastam consideravelmente a filosofia de Nietzsche do movimento transhumanista, pelo fato de o filósofo alemão operar com pressupostos ontológicos diametralmente diferentes dos empregados pelo movimento científico-filosófico contemporâneo, tivemos como objetivo problematizar o sentido mesmo do transhumanismo. A técnica, como bem nos lembra Umberto Galimberti, não nasceu como expressão do espírito humano, mas como simples remédio à sua insuficiência biológica. É por isso talvez que a técnica não possa promover aquilo que é mais caro ao pensamento de Nietzsche, e à filosofia propriamente dita, problematizar o sentido da existência. A técnica funciona, ela não se preocupa com questões relativas à vida e à morte: "Em relação ao tempo cíclico, que é o tempo da natureza, o tempo projetual é o tempo da técnica, atravessado pelas intenções humanas, que, comparadas ao tempo cíclico, só podem ter o gosto amargo das ilusões, 'puro e simples jogo', diria Nietzsche em relação ao "tempo sem meta"' (GALIMBERTI, 2006, p. 39). Nietzsche opera com o tempo que retorna, que cria, e assim, destrói e renasce; a ciência contemporânea, ao contrário, opera com o tempo que envelhece. Aqui, afirma Galimberti,

[...] a história sofre um abalo. Não mais decadência de uma idade mítica de ouro, mas progresso rumo a um futuro sem meta. A projetualidade técnica de fato indica avanço, mas não sentido da história. A contração entre 'passado recente' e 'futuro imediato', na qual se recolhe o seu agir, não permite discernir fins últimos, mas só progressos em vista da própria potencialização. De fato, a

transhumanismo também pretende "amestrar o animal de rapina 'homem', reduzi-lo a um animal manso e civilizado, doméstico" (GM, I, 11), algo que já foi tentado pela moral socrático-platônicojudaico-cristã iluminista com o prejuízo de ter enfraquecido e anulado no homem justamente aquelas forças vitais mais relevantes, levando àquilo que Nietzsche chamou de "má-consciência" e mesmo de "ressentimento" (OLIVEIRA, 2016, p. 726). 
técnica nada mais persegue que o próprio crescimento, um mero 'sim' a si mesma (GALIMBERTI, 2006, p. 40).

Qual o sentido desse "sim a si mesma"? Não estaríamos nos distanciando cada vez mais da "verdadeira" experiência imanente da existência, aquela que implica os prazeres, satisfações e alegrias, mas também os sofrimentos, perdas e agonias? Afinal, entre as condições do humano sempre estiveram presentes o nascimento e a morte; esta última, aliás, é a questão propriamente existencial que nos angustia, que nos move. Ora, a tecnologia contemporânea, parece, então, querer modificar aquilo mesmo que nos torna humanos, a nossa finitude, a nossa existência encarnada num corpo transitório e efêmero, com todas as suas “incompletudes". Há uma crença, portanto, que em breve teremos a transição do orgânico para o tecnológico. Contudo, para Nietzsche, o alémdo-homem é um ideal e uma autossuperação do próprio homem, portanto não sendo possível pensá-lo independentemente da história humana (WOODWARD, 2016, p. 291). O transhumanismo, destarte, opera com uma dicotomia — orgânico-tecnológico — que não possui lugar na filosofia nietzschiana. Neste contexto, as situações limites da vida, tais como a da memória, o sofrimento, o envelhecimento e a morte deixam de ser mistérios a serem desvelados em busca de significados, para se transformarem em meros problemas técnicos em busca de solução. Será que sobrará algum resquício do humano, apartado dos desejos, frustações, e sem a busca de significados? O que deve ser problematizado, talvez, não seja somente a ousadia científica, mas sobretudo a questão existencial, aquela que nos faz "humanos-demasiado humanos".

\section{Referências}

BABICH, B. Nietzsche's Post-Human Imperative: On the "All-too-Human" Dream of Transhumanism. In: TUNCEL, Y. (ed.). Nietzsche and Transhumanism: precursor or enemy? Newcastle: Cambridge Scholars Publishing, 2017. p. 101-132.

BLACKFORD, R. Nietzsche, the Übermensch, and Transhumanism: Philosophical Reflection. In: TUNCEL, Y. (ed.). Nietssche and Transhumanism: precursor or enemy? Newcastle: Cambridge Scholars Publishing, 2017. p. 191-204. 
BOSTROM, N. A History of Transhumanist Thought. Journal of Evolution and Technology, v. 14, n. 1, apr. 2005a.

BOSTROM, N. Transhumanist Values. Review of Contemporary Philosophy, v. 4, p. 3-14, may. 2005b.

BOSTROM, N. In defense of posthuman dignity. Bioethics, v. 19, n. 3, p. 202-214, 2005c.

CHEN, Y. et al. A single nucleotide incorporation step limits human telomerase repeat addition activity. Embo J, n. 37, 2018.

CONESE, M. et al. The Fountain of Youth: A Tale of Parabiosis, stem cells, and rejuvenation. Open Med, v. 12, p. 376-383, 2017.

DIÉGUEZ, A. Transhumanismo. Barcelona: Herder, 2016.

EL-HANI, N. C. Vida sintética: uma nova revolução. ComCiência, Campinas, n. 102, 2008.

ESFANDIARY, F. M. Are you a transhuman? Monitoring and Stimulating Your Personal Rate of Growth in a Rapidly Changing World. New York: Warner Books, 1989.

GALIMBERTI, U. Psiche e techne - o homem na idade da técnica. São Paulo: Paulus, 2006.

MANZOCCO, R. Transhumanism: Engineering the Human Condition. Chichester: Praxis/Springer, 2019.

MORE, M. Transhumanism: Toward a Futurist Philosophy. Extropy, v. 6, p. 6-12, jul. 1990. Disponível em: <http://fennetic.net/irc/extropy/ext6.pdf>. Acesso em: 02 out. 2019.

NIETZSCHE, F. W. Assim Falava Zaratustra. Trad. Paulo César de Souza. São Paulo: Companhia das Letras, 2011.

NIETZSCHE, F. W. Aurora. Trad. Paulo César de Souza. São Paulo: Companhia das Letras, 2016.

NIETZSCHE, F. W. A Genealogia da Moral. Trad. Paulo César de Souza. São Paulo: Brasiliense, 1988.

NIETZSCHE, F. W. Ecce Homo. Trad. Paulo César de Souza. São Paulo: Companhia das Letras, 1995.

NIETZSCHE, F. W. Digitale Kritische Gesamtausgabe: Werke und Briefe (eKGWB). Disponível em: <http://www.nietzschesource.org/\#eKGWB>.

NIETZSCHE, F. W. Fragmentos Póstumos, Volumen IV (1885-1889). Trad. de Juan Luis Vermal e Joan B. Llinares. Madrid: Tecnos, 2008.

OLIVEIRA, J. R. Nietzsche e o transhumanismo: em torno da questão da autossuperação do homem. Kriterion, n. 135, p. 719-739, dez. 2016.

PEARSON, K. A. Viroid Life: Perspectives on Nietzsche and the Transhuman Condition. London/New York: Routledge, 1997. 
SANDBERG, A.; BOSTROM, N. Whole Brain Emulation: A Roadmap. Technical Report. Future of Humanity Institute. Oxford: Oxford University Press, 2008.

SHETTY, R. P.; ENDY, D.; KNIGHT, T. Engineering BioBrick vectors from BioBrick parts. Journal of Biological Engineering, v. 2, n. 5, p. 1-12, 2008.

SORGNER, S. L. Nietzsche, the Overhuman and Transhumanism. Journal of Evolution and Technology, v. 20, n. 1, p. 29-42, 2009.

SORGNER, S. L. Beyond Humanism: Reflections on Trans- and Posthumanism. Journal of Evolution and Technology, v. 21, n. 2, p. 1-19, 2010.

TUNCEL, Y. (ed.). Nietzsche and Transhumanism, Precursor or enemy? Newcastle: Cambridge Scholars Publishing, 2017.

WOODWARD, A. Nietsscheanismo. Rio de Janeiro: Vozes, 2016.

RECEBIDO: $27 / 01 / 2020$

APROVADO: 20/02/2020

RECEIVED: 01/27/2020

APPROVED: 02/20/2020 